NBER WORKING PAPER SERIES

THE RISE OF STATE-CONNECTED PRIVATE OWNERS IN CHINA

\author{
Chong-En Bai \\ Chang-Tai Hsieh \\ Zheng Michael Song \\ Xin Wang \\ Working Paper 28170 \\ http://www.nber.org/papers/w28170 \\ NATIONAL BUREAU OF ECONOMIC RESEARCH \\ 1050 Massachusetts Avenue \\ Cambridge, MA 02138 \\ December 2020, Revised December 2021
}

Previously, "Special Deals from Special Investors: The Rise of State-Connected Private Owners in China." We are grateful to Emanuele Colonelli, Yasheng Huang, Ernest Liu, Yingyi Qian, Aleh Tsyvinski, Wei Xiong and Xiaodong Zhu for helpful discussions. Jin Han and Yanzun Yang provided excellent research assistance. Zheng Song acknowledges financial support from the Research Grant Council of Hong Kong. The views expressed herein are those of the authors and do not necessarily reflect the views of the National Bureau of Economic Research.

NBER working papers are circulated for discussion and comment purposes. They have not been peer-reviewed or been subject to the review by the NBER Board of Directors that accompanies official NBER publications.

(C) 2020 by Chong-En Bai, Chang-Tai Hsieh, Zheng Michael Song, and Xin Wang. All rights reserved. Short sections of text, not to exceed two paragraphs, may be quoted without explicit permission provided that full credit, including $\odot$ notice, is given to the source. 
The Rise of State-Connected Private Owners in China

Chong-En Bai, Chang-Tai Hsieh, Zheng Michael Song, and Xin Wang

NBER Working Paper No. 28170

December 2020, Revised December 2021

JEL No. E0,F0,O0,P0

\begin{abstract}
We use administrative registration records with information on the owners of all Chinese firms to document their connections through equity investments. We show that the largest private owners have direct equity ties with state owners, the next largest private owners have equity ties with private owners that themselves have equity ties with state owners, and the smallest private owners do not have any ties with state owners. The network of "state-connected" private owners has expanded over the last two decades. The share of registered capital of "state-connected" private owners increased by almost 20 percentage points between 2000 and 2019.
\end{abstract}

Chong-En Bai

School of Economics and Management

Tsinghua University

Beijing 100084

China

baichn@sem.tsinghua.edu.cn

Chang-Tai Hsieh

Booth School of Business

University of Chicago

5807 S Woodlawn Ave

Chicago, IL 60637

and NBER

chsieh@chicagoBooth.edu
Zheng Michael Song

Department of Economics

Chinese University of Hong Kong

Shatin, N.T., Hong Kong

zheng.michael.song@gmail.com

Xin Wang

Chinese University of Hong Kong

wangx2.04@gmail.com

A data appendix is available at http://www.nber.org/data-appendix/w28170 


\section{Introduction}

The economic transformation of China over the last few decades has been associated with the decline of the state sector and rise of the private sector. For example, the share of state owned firms in Chinese industrial output fell from 50 to under 30 percent between the late 1990s and early 2010s. ${ }^{1}$ This basic fact led many observers to conclude that China's growth was driven, in a proximate sense at least, by the expansion of the private sector, by the triumph of "Markets over Mao" to use Lardy (2014)'s pithy phrase. ${ }^{2}$

This paper uses administrative registration records of all Chinese firms to show that the distinction between state and private ownership behind this narrative is increasingly blurry. The key feature of the registration data is that it identifies the owners of the universe of Chinese firms. We use this to identify firms with equity investments from state owners and from private owners with equity ties to state-owned firms.

We report three key facts. First, large private owners in China today typically have joint ventures with state owners. Among the largest one thousand private owners in China in 2019, about 65\% had equity investments from state owners. We find more than a hundred thousand private owners in China in 2019 with equity investments from state owners. These state-connected private owners collectively account for more than $15 \%$ of all registered capital in China.

Second, the largest private owners in China also hold equity in the companies of other, typically smaller, private owners. In turn, the latter also invest in joint ventures with other, even smaller, private owners, and so on. In 2019, there were a total of 3.5 million owners with "indirect" ties to state owners. The registered capital of these indirectly connected owners accounted for $18 \%$ of total registered capital in 2019.

Third, the network of private owners connected to the state has expanded over the last 20 years. The number of private owners with direct investments from the state almost tripled between 2000 and 2019, and the number of private owners indirectly connected to the state via investments from private owners with state connections increased 50-fold. The increase in the registration capital share of the two groups of stateconnected private owners accounts for almost all the 20 percentage point increase in the share of private owners between 2000 and 2019.

\footnotetext{
${ }^{1}$ See Figure 1 in Hsieh and Song (2015).

${ }^{2}$ See also Brandt and Zhu (2010), Song et al. (2011), Zhu (2012).
} 
The paper proceeds as follows. The next section describes the firm registration data. We then use the registration data to present six facts about the equity links between state and private owners in China. The last section discusses the implications of these facts.

\section{Chinese Firm Registration Data}

We use the firm registration records of the State Administration for Market Regulation. ${ }^{3}$ All Chinese firms are legally obligated to register with this body. In addition, the registration data identifies each firm's immediate owners. These owners can be an individual person, a "legal person," or other private organizations (including the traded shares of publicly listed companies). Most legal-person owners are other firms, but we know that some are holding shells. In most countries, we would not know the owners of holding shells but a key feature of the Chinese data is that all Chinese holding shells as well as their owners also appear in the registry. ${ }^{4}$ If the owners of the holding shells are themselves holding shelves (which is typically the case for large Chinese firms), we continue to peel off the ownership layers until we find the "ultimate" owners.

Take the East Hope Group, a large conglomerate in the heavy metals and animal food industries. The two dark circles at the bottom of Figure 1 represent two companies in the Group, East Hope Aluminum and Dachang Mining, and the circles directly linked to these firms represent their immediate owners.

The immediate owners of East Hope Aluminum, one of the largest alumina producers in China, are three holding shells, two registered in Hong Kong and one in China. The immediate owners of the Chinese holding shell are two other holding shells that are themselves fully owned by the family of the founder of the East Hope Group. Foreign holding shells are not in the registration data, but we have evidence that the two HongKong holding shells are fully owned by same East Hope family. ${ }^{5}$ East Hope Aluminum is

\footnotetext{
${ }^{3}$ Recent papers by Dai et al. (2019), Shi et al. (2020), Brandt et al. (2019), Allen et al. (2019) and Bai et al. (2021) use the same registration data to examine different questions.

${ }^{4}$ Foreign legal-person owners are not registered in China so we do not know their owners. Foreign holding companies ("variable interest entities") that do not formally own equity in the firm will not appear among the owners. See Appendix A for the importance of foreign legal person owners and Coppola et al. (2021) for estimates of the importance of Chinese "variable interest entities."

${ }^{5}$ See the announcement by Mingsheng Bank (http://stock.finance.sina.com.cn/hkstock/go/ CompanyNoticeDetail/code/01988/aid/488702.html).
} 
Figure 1: Owners of East Hope Aluminum and Dachang Mining

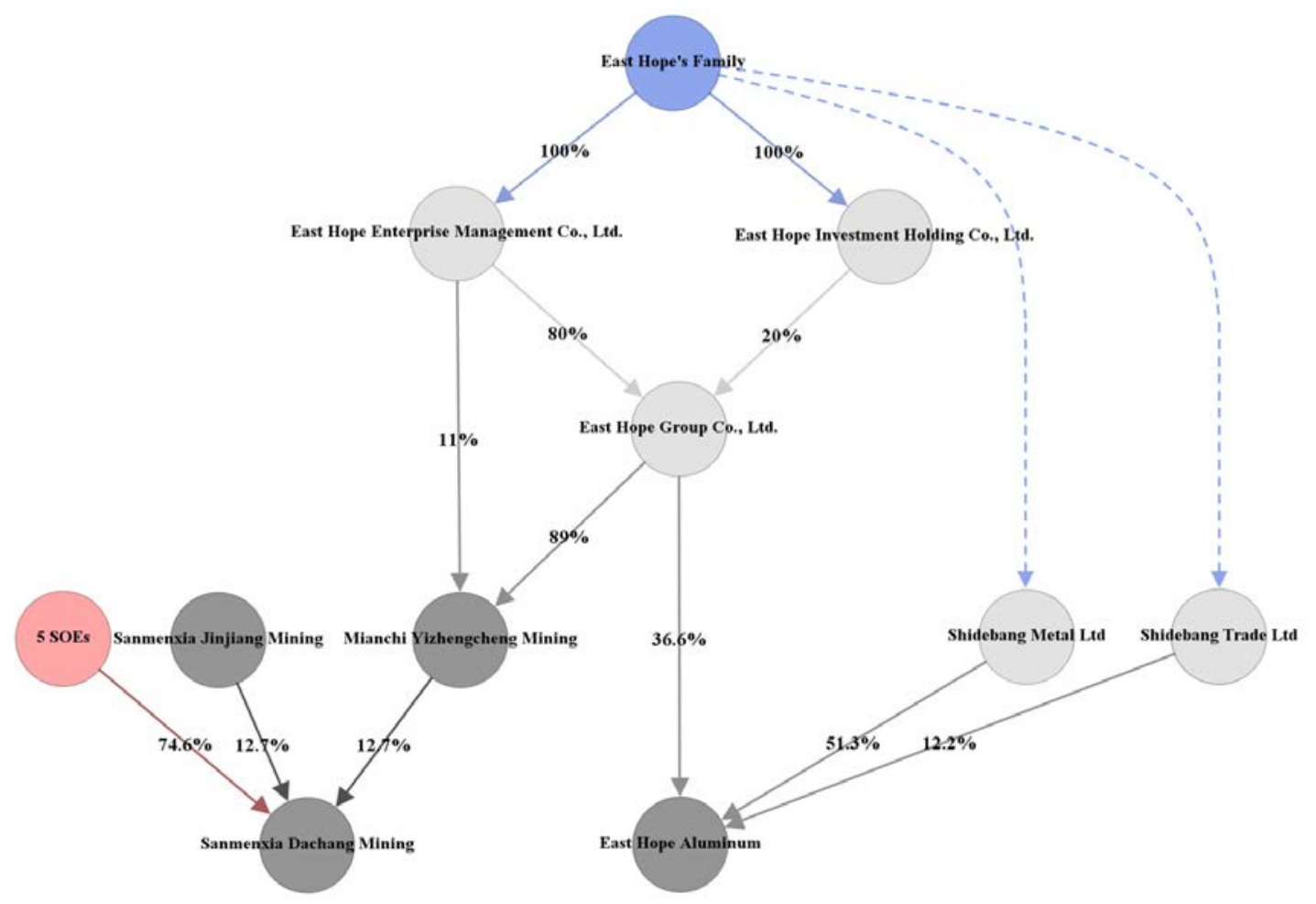

Note: East Hope Aluminum and Dachang Mining are the two dark gray circles at the bottom of the figure. The other circles represent the owners of East Hope Aluminum and Dachang Mining. Dark gray circles represent "real" private companies, light grey (suspected) holding shells, red for state-owned firms, and blue for individual owners.

therefore wholly owned by East Hope's family through a sequence of five holding shells.

The immediate owners of Dachang Mining, a bauxite mining company, are five state-owned firms and two private companies. One of the private companies (Mianchi Yizhengcheng) is fully owned by East Hope's family through a sequence of holding shells, and the other private company (Sanmenxia Jinjiang) is fully owned by the Hangzhou Jinjiang Group. The ultimate owners of Dachang Mining are therefore East Hope's family, the owners of the Hangzhou Jinjiang Group, and five state owned firms.

We undertake the same exercise for every Chinese firm. That is, we work through each firm's ownership chain until we identify their ultimate owners. ${ }^{6}$ These ultimate

\footnotetext{
${ }^{6}$ We calculate the shares of $n$ ultimate owners in $m$ firms as $Z=[\mathbb{I}-X]^{-1} Y$ where $\mathbb{I}$ is the identity matrix, $X$ is a $m \times m$ matrix of the ownership share of each firm in the other firms and $Y$ is a $m \times n$ matrix of immediate ownership share of the ultimate owners in each firm.
} 
owners can be an individual person, a state owner, a foreign owner, or a private organization (which includes the publicly traded shares of a listed company). ${ }^{7}$ We then measure the connections in the form of joint ventures between these owners. In the previous example, this exercise reveals that East Hope's family is connected with five state owned firms through their joint ownership of Dachang Mining.

The only economic information in the registry is the firm's registered capital. Chinese law stipulates that owners need to pay the "registration capital" into the company's account. This registration capital represents the maximum liability of the owners in the event of a default. Many sectors specify a minimum registered capital, but generally registered capital is determined by the amount of real business the firm needs to undertake. Registered capital of holding shells is minimal and a poor measure of the value of its assets, but a reasonable proxy of the assets and sales of a "real" firm. ${ }^{8}$ For every owner, we add up registered capital of all the firms in which they have an equity stake weighted by their ownership share of the firm, and call this the "owner's capital."

We have the registration records in 2013 and 2019. The data in each year contains the records of firms active in that year and the firms that had exited by then. We use the 2019 records to identify the owners (and registration capital) of firms active in 2019, and the 2013 records to identify firms active in 2000 and 2010. We assume a firm was active in 2000 (2010) if it was established prior to 2000 (2010) and had not exited by 2000 (2010)..$^{10}$

The ownership and registration capital reported in the data are for the most recent year the firm shows up in the data. The owners of the firms active in 2019 are the owners of the firms in 2019. For the firms in 2000 or 2010, if the firm was still active in 2013 we assume the owners are the same as that reported in 2013. For the firms that exited prior to 2013 , we assume the owners in 2000 or 2010 are the same as the owners in the year the firm exited the data.

\footnotetext{
${ }^{7}$ Appendix A shows the number of ultimate owners and the registration capital share of each type of ultimate owner.

${ }^{8}$ Appendix B shows that registered capital is highly correlated with sales and assets of industrial firms.

${ }^{9}$ Owner's capital is calculated as $Z^{\prime} K_{F}$ where $Z$ is a $m \times n$ matrix of the ownership shares of $n$ owners in $m$ firms and $K_{F}$ is a $m \times 1$ vector of the registered capital of $m$ firms.

${ }^{10}$ Appendix A checks the imputation of active firms by comparing firms in 2013 imputed from the 2019 data with the firms observed in the 2013 data.
} 


\section{State-Connected Private Owners}

In the previous section, we showed that East Hope's family is connected with five state owned firms and the Hangzhou Jinjiang Group through their joint ownership of Dachang Mining. In this section, we look at the prevalence of joint ventures between owners of all Chinese firms.

We start by examining all the companies in the East Hope Group (Dachang Mining and East Hope Aluminum are only two of the companies in the group). There are a total of 236 companies in 2019 in which East Hope's family owns at least a 10\% equity share. Among these companies, 210 are wholly owned by the family and 26 are joint ventures. Focusing on the joint ventures, 14 of them are with state owners. We will say then that East Hope's family is directly connected to the state via these joint ventures. The state owners are typically much larger than East Hope itself. The average registered capital of these state owners is 80 billion yuan: the equivalent number for East Hope's family is 26 billion.

The remaining 12 joint ventures are with 9 other private owners, and these private owners are typically smaller than East Hope. The average registered capital of these private owner is 6 billion yuan. Furthermore, 6 of private owners do not have investments with state-owners so their only connection to the state is via their joint venture with East Hope. We will say that these 6 owners are "indirectly connected" to the state.

We next show that the ownership ties seen in the East Hope Group holds more generally across all the owners in China. We use the following definitions:

- State Owners: A state owner is either a branch of central, provincial, city, or county level government, or a firm that is directly and wholly owned by a local government or the central government. ${ }^{11}$

- "Directly" and "Indirectly" Connected Private Owners: Directly connected private owners own at least $10 \%$ of a joint venture with state owners. ${ }^{12}$ Private owners whose only connection with a state owner is via a joint venture with another private owner are indirectly connected.

\footnotetext{
${ }^{11}$ See Appendix $\mathrm{C}$ for details.

${ }^{12}$ The state owner also has to own at least $10 \%$ of the joint venture.
} 
- "Distance" to the State: The minimum number of private owners between the private owner and the state +1 defined as $d_{i}=\min _{j \in O_{i}}\left\{d_{j}\right\}+1$ where $O_{i}$ is the set of owners directly connected to owner $i$. Distance $=0$ for a state owners and distance $=1$ for directly connected private owners such as East Hope's family.

- "Downward" and "Upward" Connections: Consider two connected owners A and $B$ that have a joint venture together. If $B$ is more distant from the state than $A$, then A has a "downward" connection with B, and B has an "upward" connection with A.

We summarize these links as six facts.

Fact 1: Large private owners are "connected"

Table 1: Connected Owners Among Top Private Owners, 2019

\begin{tabular}{lccccc}
\hline & Top & Top & Top & Top & $>$ Top \\
& 100 & $100-1 \mathrm{k}$ & $1 \mathrm{k}-10 \mathrm{k}$ & $10 \mathrm{k}-100 \mathrm{k}$ & $100 \mathrm{k}$ \\
\cline { 2 - 6 } \% State Connected & $78 \%$ & $78 \%$ & $70 \%$ & $58 \%$ & $6 \%$ \\
\% Directly Connected & $65 \%$ & $63 \%$ & $44 \%$ & $17 \%$ & $.2 \%$ \\
\% Indirectly Connected & $13 \%$ & $14 \%$ & $27 \%$ & $40 \%$ & $5 \%$ \\
Connected Private Owners & & & & & \\
\% Capital in Upward JVs & $30 \%$ & $24 \%$ & $26 \%$ & $28 \%$ & $41 \%$ \\
\% with Downward JVs & $76 \%$ & $83 \%$ & $77 \%$ & $77 \%$ & $37 \%$ \\
\% Capital in Downward JVs & $10 \%$ & $12 \%$ & $16 \%$ & $25 \%$ & $28 \%$ \\
\hline
\end{tabular}

Note: Table shows share of of connected private owners among each group of top private owners, where the size of an owner is measured by the sum of its registered capital in all the firms it owns. Directly connected private owners have joint ventures with a state owner. Indirectly connected private owners have a joint venture with another private owner that has a connection with a state owner. \% Capital in Upward (Downward) JVs is the share of the owner's capital in the joint venture with the owner that is closer to (further from) the state. \% with Downward JVs is the share of owners that have equity ties with owners that are more distant from the state.

Table 1 ranks private owners by registered capital in 2019. The top panel shows the share of each group of private owners connected to state owners through joint ventures. Among the top 1000 private owners about $78 \%$ are state-connected, mostly through direct joint ventures with state owners. 
Fact 2: Smaller owners are more likely to be indirectly connected to the state or not connected at all.

Table 1 shows that smaller owners are more likely to be indirectly connected whereas larger owners (such as East Hope's family) are typically directly connected. For example, about $40 \%$ of owners among the top ten to hundred thousand owners are indirectly connected to the state, compared to only $14 \%$ of of the top thousand owners. The probability of being connected (direct or indirect) also falls with size. Among owners smaller than the top hundred thousand, the vast majority (94\%) have no connection with the state.

Fact 3: The majority of a state-connected owner's businesses are fully owned by the owner

In the case of the East Hope Group, although many of the companies in the group are joint ventures, it is still the case that the majority of the companies in the Group are fully owned by East Hope's family. We now show that the same is likely to be true for the typical connected private owner.

The first row in the bottom panel in Table 1 shows that the share of the owner's registered capital in the upward joint venture is typically around $25 \%$ and only exceeds $40 \%$ for the very smallest owners (owners smaller than the top hundred thousand). The last two rows in Table 1 looks at the importance of downward joint ventures. First, the table shows that about $75 \%$ of connected private owners among the top hundred thousand owners also have downward connections with other owners. It is only when we move outside the top hundred thousand that the share of connected owners with downward connections falls significantly. Second, downward joint ventures typically account for a small share of the owner's capital. This share is $10 \%$ for the top 100 owners and rises as we consider smaller owners.

\section{Fact 4: Connected private owners are more important in state-dominated sectors}

Figure 2 shows that phenomena of state-connected private owners is particularly im-

portant in state-dominated sectors. The figure shows the share of private firms in a two-digit industry that are direct joint ventures with state-owners (red hollow circles) 
or indirectly connected to the state (blue filled circles) as a function of the share of state owners in the sector. ${ }^{13}$ There is a clear positive relationship, particularly for the share of indirectly connected private owners: an OLS regression of the share of indirectly connected private owners on the state share yields a coefficient of .78 (s.e $=.06, R^{2}=$ .62). The coefficient from a similar regression of the share of directly connected private owners on the state share is .23 (s.e $=.04, R^{2}=.27$ ).

Figure 2: Share of Connected Private Owners vs. State Share in Industry

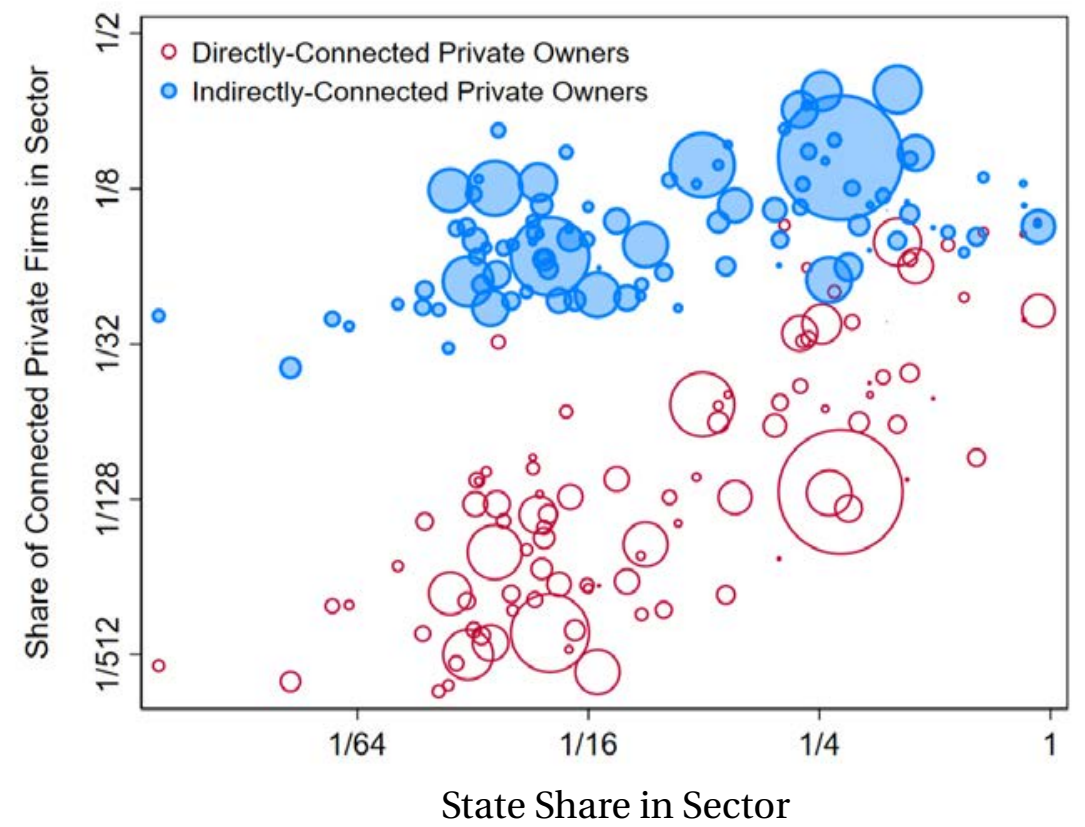

Note: Each observation is a two-digit industry in 2019. Red hollow circles plot the share of private firms directly connected with state owners in all private firms in a two-digit industry (y-axis) vs. the state share of registered capital in the industry (x-axis). Filled blue circles show the proportion of firms indirectly connected with state owners in all private firms but joint ventures with state owners against the state share of registered capital in the industry. State share on the $\mathrm{x}$-axis is the share of firms fully owned by the state in total registered capital in the industry (registered capital of state owners in their joint ventures with private owners are excluded). The size of a circle measures total registered capital of all firms in the industry.

\section{Fact 5: The number of private owners connected to the state has increased}

Figure 3 shows that average number of downward connections per owner (left panel) and the number of connected owners in 2000, 2010, and 2019 by distance to the state.

\footnotetext{
${ }^{13}$ The state share is the share of registered capital of firms wholly owned by the state (excluding the capital of state owners in their joint ventures with private owners) in total registered capital in the industry.
} 
Given the definition of distance, state owners have distance $=0$ and private owners have distance $>0$. The number of state owners with joint ventures with private owners was roughly constant over this period, but the average number of joint ventures per state owner increased from 3.5 in 2000 to almost 15 by 2019. The effect of the increase in the number of joint ventures per state owner is that the number of private owners directly connected to the state (distance $=1$ ) increased by almost a factor of 3 between 2000 and 2019.

Figure 3: Increase in Number of Connected Owners, 2000-2019

Connections per Owner

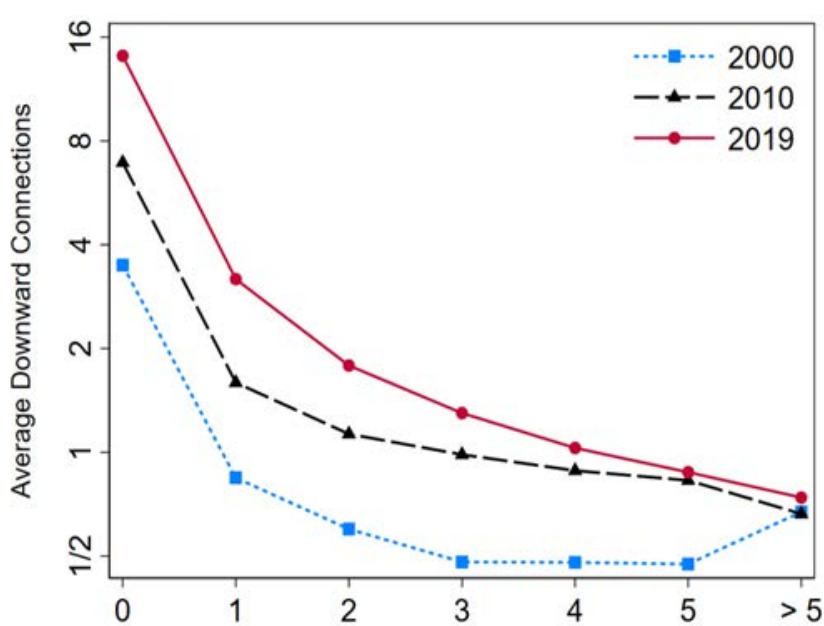

\# Connected Owners

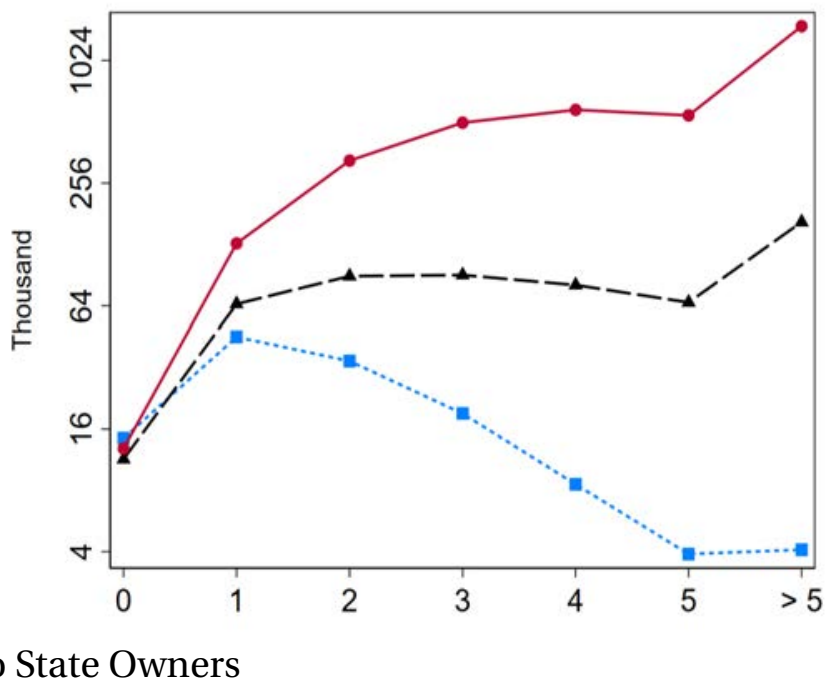

Note: Left panel shows the average number of downward connections per state or private owner by distance to the state in 2000,2010 , and 2019. Right panel shows the total number of connected state and private owners (in thousands) by distance to the state in 2000, 2010, and 2019. Distance $=0$ are state owners, Distance $=1$ are private owners with investments from state owners, and Distance $>1$ are private owners that do not have direct investments from state owners.

The right panel also shows that the number of private owners indirectly connected to the state also increased. This effect is particularly dramatic for owners very distant from the state. The number of owners with distance $>5$ increased from around 4 thousand in 2000 to more than 1.5 million by 2019. The huge increase in the number of indirectly connected owners is driven, in a proximate sense, by the increase in the number of private owners directly connected to the state (distance $=1$ ) and by the increase in the number of downward connections per private owner (left panel in Figure 
$3)$.

More formally, the change in the number of connected owners can be decomposed into the following two terms:

$$
\Delta N\left(1+\sum_{d=2}^{d^{*}-1} \prod_{s=1}^{d-1} C_{s}\right)+N \sum_{d=2}^{d^{*}-1} \Delta\left(\prod_{s=1}^{d-1} C_{s}\right)
$$

where $N$ is the number of owners directly connected to state owners, $C_{s}$ is the number of downward connections per owner at distance $s$, and $d^{*}$ is the maximum distance of a state-connected firm. The first term is the effect of the increase in the number of directly connected owners, holding fixed the number of connections per private owner. The second term is the effect of the increase in the number of connections per private owner, holding fixed the number of directly connected owners. In our data, this decomposition suggests that most of the increase in the number of connected owners comes from the second term. Specifically, the increase in investments by private owners in other firms accounts for $88.5 \%$ of the increase in the number of connected owners over the $2000-2010$ period, and for $82.1 \%$ of the increase over the $2010-2019$ period.

\section{Fact 6: Connected private owners account for almost all the increased share of private owners}

A well-known fact about China's growth is the decline in the size of the state sector and the expansion of the private sector. The top panel in table 2 shows that in the registration data, the share of private owners in total registered capital increased by 22 percentage points between 2000 and 2019. The next two columns show the share of state-connected private owners in total registration capital increased by 19.4 percentage points over the same period. So almost all of the increase in the share of private owners comes from the expansion of the state-connected private sector. In addition, most of this comes from the expansion of owners that are indirectly connected vs. owners that have direct equity ties with state-owners.

The bottom panel shows the registration capital share of state owners that have invested in private owners. We consider two definitions of the state share: the share of equity owned by state owners (the same definition we use for share of private owners in the top panel) and the share controlled by state owners. For the latter, we identify firms 
where a state owner is the controlling ultimate owner and allocate all the registered capital of the firm to the state owner. ${ }^{14}$ We also consider all state owners as one owner, and identify firms where the collective state sector is the controlling ultimate owner.

The results are shown in the bottom panel in Table 2. Column 1 shows that the share of state owners as measured by their equity share falls by 16 percentage points between 2000 and 2019. The next two columns shows the share of registered capital controlled by state owners, where we treat each state owner as a separate owner (column 2) or as one collective owner (column 3). Compared to the share of equity owned by state owners in column 1, the share controlled by state owners falls by even more, particularly when state owners as viewed as one collective owner. The registration capital share of connected state owners falls by 16.9 percentage points between 2000 and 2019 when each state owner is treated as a separate owner and by 21.4 percentage points when the state owners are regarded as one collective owner.

\section{Discussion}

Our key message is that state owners increasingly invest in large private owners, and that these large private owners have invested in smaller private owners. The net effect is that a large share of the Chinese economy is neither completely state owned nor completely privately owned but is rather this gray zone with mixed ownership.

A natural question is why we see such equity partnerships. In the case of East Hope Group, we have narrative evidence that connected owners were critical in enabling East Hope's family to grow beyond their original business (animal feed). For example, East Hope Aluminum was originally a joint venture between East Hope and Huanghe Aluminum and Electricity, a state firm owned by the city of Sanmenxia (Henan Province). This partnership made it possible for East Hope to enter the alumina market that, at the time, was reserved for the state-owned company Chinalco. The evidence in Figure 2 that these partnerships are more important in state dominated industries suggests that many other firms followed East Hope's model to penetrate sectors dominated by

\footnotetext{
${ }^{14}$ When a firm has no immediate legal-person owner, we define its controlling ultimate owner as the owner with the largest equity share. When the firms has immediate legal-person owners, we identify the controlling ultimate owners for the legal-persons first and then replace the firm's immediate legal-persons with their corresponding controlling ultimate owners. This allows us to identify the firm's controlling ultimate owner as the ultimate owner with the largest controlling share.
} 
Table 2: Share of Connected Owners in Registered Capital, 2000-2019

\begin{tabular}{|c|c|c|c|}
\hline & \multicolumn{3}{|c|}{ Share of Private Owners } \\
\hline & All & $\begin{array}{l}\text { Directly } \\
\text { Connected }\end{array}$ & $\begin{array}{l}\text { Indirectly } \\
\text { Connected }\end{array}$ \\
\hline 2000 & $54.7 \%$ & $9.9 \%$ & $4.2 \%$ \\
\hline 2010 & $64.6 \%$ & $13.9 \%$ & $10.1 \%$ \\
\hline \multirow[t]{3}{*}{2019} & $76.7 \%$ & $15.3 \%$ & $18.2 \%$ \\
\hline & \multicolumn{3}{|c|}{ Share of Connected State Owners } \\
\hline & Cash Flow & $\begin{array}{l}\text { Control } \\
\text { Separate Owners }\end{array}$ & One Owner \\
\hline 2000 & $38.5 \%$ & $40.0 \%$ & $47.4 \%$ \\
\hline 2010 & $33.0 \%$ & $34.9 \%$ & $38.3 \%$ \\
\hline 2019 & $22.5 \%$ & $23.1 \%$ & $26.0 \%$ \\
\hline
\end{tabular}

Note: Top panel shows share of private owners in total registered capital. Directly connected private owners have joint ventures with state owners. Indirectly connected private owners are linked to the state through another private owner. "All private" includes unconnected and connected private owners. Bottom panel shows share of state owners with joint ventures with private owners. "Cash flow" shows ownership share of connected state owners. "Control rights" allocate all the registered capital of a firm to the state owner if the state owner is the controlling shareholder. "Separate Owner" treats each state owner as an individual owner; "One Owner" treats all state owners as one owner.

state owners.

If owners that get connected get benefits from their connected investor, then the increase in the number of connected owners potentially increases aggregate productivity, and may be an important part of the explanation behind China's rapid growth. However, it is also possible that the growth of the connected sector reflects the "grabbing hand" of the government, or the desire by the state to have more control over the private sector. If this view is correct, then the rise of state connected private owners reflects a tax that presumably limits their growth.

However, the "grabbing hand" interpretation is inconsistent with several facts shown in this paper. First, state owners own a small share of the businesses of the private owners they invest in. Second, the share controlled by state owners has fallen by even more than the share owned by the state. Third, it does not explain why private owners have 
increasingly also invested in the businesses of other private owners. Fourth, firms with indirect connections are more prevalent in state dominated sectors, and state owners do not own any equity in the firms of indirectly connected owners. This evidence is only suggestive of course, and our hope is to make progress on this debate in future work. 


\section{References}

Allen, Franklin, Junhui Cai, Xian Gu, Jun “QJ" Qian, Linda H. Zhao, and Wu Zhu, "Ownership Network and Firm Growth: What Do Five Million Companies Tell About Chinese Economy," 2019.

Bai, Chong-En, Ruixue Jia, Hongbin Li, and Xin Wang, "Entrepreneurial Reluctance: Talent and Firm Creation in China," 2021.

Brandt, Loren and Xiaodong Zhu, "Accounting for China’s growth," 2010.

_, Ruochen Dai, Gueorgui Kambourov, Kjetil Storesletten, and Xiaobo Zhang, "Serial Entrepreneurship in China," 2019.

Coppola, Antonio, Brent Neiman, Matteo Maggiori, and Jesse Schreger, "Redrawing the Map of Global Capital Flows: The Role of Cross-Border Financing and Tax Havens," Quarterly Journal of Economics (forthcoming), 2021.

Dai, Ruochen, Dilip Mookherjee, Kaivan Munshi, and Xiaobo Zhang, “The Community Origins of Private Enterprise in China," 2019.

Hsieh, Chang-Tai and Zheng Michael Song, "Grasp the Large, Let Go of the Small: The Transformation of the State Sector in China," Brookings Papers on Economic Activity, 2015.

Lardy, Nicholas, Markets over Mao: The Rise of Private Business in China, Peterson Institute for International Economics, 2014.

Shi, Xiangyu, Tianyang Xi, Xiaobo Zhang, and Yifan Zhang, “"Moving Umbrella”: Identifying Collusion Through Bureaucratic Transfers And Investment Flows,” 2020.

Song, Zheng, Kjetil Storesletten, and Fabrizio Zilibotti, “Growing like china,” American economic review, 2011, 101 (1), 196-233.

Zhu, Xiaodong, "Understanding China's growth: Past, present, and future," Journal of Economic Perspectives, 2012, 26 (4), 103-24. 


\title{
Online Appendix The Rise of State-Connected Private Owners in China
}

\author{
(Not for publication)
}

\section{A Summary Statistics}

Table A.1 shows the number of active firms and owners. Table A.2 shows the share of registration capital owned by the different groups of owners. Table A.3 compares the data on the owners in 2013 inferred from the 2019 data with the data on owners in the 2013 data.

Table A.1: Number of Firms and Ultimate Owners, 2000-2019

\begin{tabular}{ccccccc}
\hline & \multirow{5}{*}{ Firms } & \multicolumn{5}{c}{ Owners } \\
\cline { 3 - 7 } & & All & State & Individuals & Foreign & Other \\
\cline { 2 - 7 } 2000 & 4,320 & 5,540 & 257 & 4,635 & 43 & 606 \\
2010 & 9,670 & 19,411 & 105 & 18,791 & 89 & 427 \\
2019 & 37,546 & 62,887 & 63 & 62,188 & 140 & 496 \\
\hline
\end{tabular}

Note: Table shows the number of firms and owners (in thousands) in each year in the registration data. Other includes private organizations and publicly traded shares of listed companies.

Table A.2: Registered Capital Share of Ultimate Owners, 2000-2019

\begin{tabular}{ccccc}
\hline & State & Individuals & Foreign & Other \\
\cline { 2 - 5 } 2000 & $45.3 \%$ & $22.1 \%$ & $7.3 \%$ & $25.4 \%$ \\
2010 & $35.4 \%$ & $38.6 \%$ & $8.9 \%$ & $17.1 \%$ \\
2019 & $23.3 \%$ & $63.0 \%$ & $8.2 \%$ & $6.5 \%$ \\
\hline
\end{tabular}

Note: Table shows registered capital share of state owners, individual owners, foreign legal person owners, and other private organizations. 
Table A.3: Inferred vs Real 2013 Data

\begin{tabular}{lcc}
\hline & Real & Inferred \\
\cline { 2 - 3 } \# Active Firms & $14,121,908$ & $14,125,941$ \\
\# Ultimate Owners & $29,082,604$ & $30,158,962$ \\
State & 93,348 & 64,998 \\
Private & $28,989,256$ & $30,093,964$ \\
\% Registered Capital & & \\
State & $32.6 \%$ & $33.2 \%$ \\
Private & $67.4 \%$ & $66.8 \%$ \\
\hline
\end{tabular}

Note: "Real" uses the 2013 data. "Inferred" uses the 2019 data to calculate the statistics of firms and owners in 2013.

\section{B Registered Capital}

Table A.4 compares a company's registered capital with the firm's sales and assets in the industrial sectors. Specifically, in first two columns, we merge the 2013 firm registration records with the micro-data from the 2013 Chinese Annual Industrial Survey. We then regress the firm's registration capital (from the registration data) on total assets and sales (from the micro-data of the Industrial Survey). For example, a regression of firm's log registered capital on its log total assets (sales) yields a coefficient of $0.93(0.65)$ with a $R^{2}$ of $0.48(0.16)$.

Table A.4: Regression of registered capital on firm assets and sales for industrial firms

\begin{tabular}{|c|c|c|c|c|c|c|c|c|}
\hline & \multicolumn{2}{|c|}{2013} & \multicolumn{2}{|c|}{2007} & \multicolumn{2}{|c|}{2002} & \multicolumn{2}{|c|}{1998} \\
\hline & Assets & Sales & Assets & Sales & Assets & Sales & Assets & Sales \\
\hline & $\begin{array}{c}0.926 \\
(0.000)\end{array}$ & $\begin{array}{c}0.648 \\
(0.000)\end{array}$ & $\begin{array}{c}0.966 \\
(0.000)\end{array}$ & $\begin{array}{c}0.859 \\
(0.000)\end{array}$ & $\begin{array}{c}0.948 \\
(0.000)\end{array}$ & $\begin{array}{c}0.895 \\
(0.000)\end{array}$ & $\begin{array}{c}0.906 \\
(0.000)\end{array}$ & $\begin{array}{c}0.874 \\
(0.000)\end{array}$ \\
\hline$R^{2}$ & 0.48 & 0.16 & 0.54 & 0.27 & 0.54 & 0.31 & 0.53 & 0.29 \\
\hline
\end{tabular}

Note: The unit of observation are firms in the 1998, 2002, 2007, and 2013 industrial surveys matched with firms in the 2013 registration data. The dependent variable is log registered capital from the 2013 registration data. The independent variables are log total assets or log total sales from the 2013, 2007, 2002, and 1998 industrial firm surveys.

Shareholders are allowed to change (mostly increase) the registered capital of their company. To do this, they need to report to the local office of State Administration for Market Regulation. Once the application is approved, the company's business license will be changed accordingly. As a result, what we see from the 2013 registration records is the firm's most up-to- 
date registered capital by the end of 2013. We do not have information on the firm's historical registration capital. However, since we use registered capital as a proxy for firm size, we can check how the 2013 registration data aligns with contemporaneous data on total assets and sales in previous years for the same firm. The columns starting in column 3 in Table A.4 show the results when we merge the 2013 registration records with earlier industrial surveys in 2007, 2002, and 1998. As can be seen, the regression coefficients are virtually the same as in the first two columns.

Lastly, we also investigate the potential bias caused by holding shells. Specifically, we check this by measuring the total registered capital of industrial firms in the Annual Industrial Survey that belong to a given owner and comparing this number to the total registered capital in the registration data including the registered capital of all the intermediate owners. A regression of log registered capital of firms in the industrial data on the log registered capital of all firms that belong to the same owner, including all the intermediate firms in the registration data, yields a coefficient of 0.92 and an $R^{2}$ of 0.91 .

\section{Identification of State Owners}

We identify whether a shareholder is state owner or not by its name. Specifically, we compiled a list of Chinese central, provincial, city- and county-level administrative divisions. We also compiled a list of all the departments at each level of government. To make the list complete, we include all possible combinations of division (e.g., Beijing) and department (e.g., Bureau of Finance). Then we match the name of the shareholder in the registration data with our list of state owners. ${ }^{15}$

We treat all the departments that belong to the same level of government as one state owner. For example, we treat the Department of Finance of Shandong Province and the SASAC (StateOwned Assets Supervision and Administration Commission) of Shandong Province as the same owner as both are different departments of the Shandong provincial government. However, we assume that the government of Shandong Province and the government of Jinan City (the capital city of Shandong) are two different owners. The exception to this rule is that if a state firm is directly and $100 \%$ owned by a government, we classify it as a separate state owner. For example, although SAIC is owned by Shanghai's SASAC, we assume SAIC is a separate state

\footnotetext{
${ }^{15}$ We also identify state owners by searching several keywords in shareholder's name as supplementary to the list.
} 
owner. $^{16}$

\footnotetext{
${ }^{16} \mathrm{We}$ also checked around 7 thousand local government financing vehicles (LGFV). About a quarter of them are classified as state owners by our definition. For example, Shanghai Guosheng Group Co. is identified as a state owner because it is directly and $100 \%$ owned by SASAC of Shanghai. Another LGFV, Shanghai State-owned Assets Operation Co., is not identified as a state owner because it is owned by Shanghai International Group Co., which is a state owner.
} 